\section{International Scientific Journal Theoretical \& Applied Science}

\author{
p-ISSN: 2308-4944 (print) e-ISSN: 2409-0085 (online) \\ Year: 2017 Issue: 11 Volume: 55 \\ Published: $24.11 .2017 \quad$ http://T-Science.org
}

SECTION 21. Pedagogy. Psychology. Innovations in the field of education.
Svetlana Vasilyevna Meleshko Assistant of Mathematics Department, Stavropol State Agrarian University, Russia, Stavropol meleshko-78@mail.ru

Elena Borisovna Zorina Associate Professor, Candidate of Pedagodical science, Head of Foreign languages and cross-cultural Department, Stavropol State Agrarian University, Russia,Stavropol zeb26@mail.ru

Svetlana Viktorovna Popova Senior Lecturer of Mathematics Department, Stavropol State Agrarian University, Russia, Stavropol svp0314@yandex.ru

Tatyana Aleksandrovna Gulay

Candidate of Technical Sciences, Associate Professor of Mathematics Department, Stavropol State Agrarian University, Russia, Stavropol laima5566@mail.ru

\title{
DISTANCE TECHNOLOGIES AS INTEGRAL PART OF UNIFIED EDUCATIONAL SPACE
}

Abstract: This paper refers to the information technologies in the educational process and, in particular, distance learning technology of students, its strengths and weaknesses.

Key words: information technology, distance education, common education information space.

Language: English

Citation: Meleshko SV, Zorina EB, Popova SV, Gulay TA (2017) DISTANCE TECHNOLOGIES AS INTEGRAL PART OF UNIFIED EDUCATIONAL SPACE. ISJ Theoretical \& Applied Science, 11 (55): 89-91.

Soi: http://s-o-i.org/1.1/TAS-11-55-12 Doi: crostef https://dx.doi.org/10.15863/TAS.2017.11.55.12

\section{Introduction}

The widespread introduction of information technologies in human life in modern society is a global process. Education being the Foundation of civilized society keeps pace with the times and actively applies them in the educational process. The introduction of information technology has an influence on the quality and content of education. Information technology stimulate the students in learning. Their use can provide students with more opportunities for independent work, helps flexibility to vary the training schedule. Multimedia products and Internet services are good helpers for critical thinking development.

\section{Materials and Methods}

According to experts, new information technologies training to improve the effectiveness of practical and laboratory classes for science no less than $30 \%$, the objectivity of knowledge control of students - 20-25\%. Performance in the control groups, using educational IT is typically higher on average by 0.5 points (with a five-point rating system).

In this regard, the main directions of education informatization are as follows:

- implementation of a virtual informationeducational environment at the level of the institution, providing the implementation of complex of works on creation and maintenance of technologies of its operation;

- system integration of information technology in education, supporting learning processes, research and organizational management;

- establishment and development of unified educational information space. [1]

Essentially we are talking about solving the problem of qualitative change of the entire 
information environment of the education system to provide new opportunities for advancing, developing education of each individual and for the growth of the total social intelligence. [11]

An important and effective condition of progress of any society is the establishment and expansion of a single interactive information space. It is a unified information space has historically been largely accelerated the development of humanity as a whole, is a decisive factor of the development of civilization in all spheres (spiritual, professional, physical, cultural and others).

Therefore, the creation of a single interactive information space can be considered a strategic goal for the introduction of modern and perspective information technologies in all spheres of human activity. [10]

Considering the modern education as a process, we can note its main characteristics: integrity, purposefulness, and sociality. [3] Education is a set of processes of training and education, the purpose and result of which is the development of the individual, including in the virtual-real space. We can say that education is not only training, but also education of the individual, aimed at creating an image by gaining individual experience in the process of development of the system of knowledge, experience and culture of mankind. For example, the distance education modern society has become convinced that information technology increases the value of education, ensure personal development in an open virtual education, help to adapt to a complex and contradictory world of knowledge. [2]

Information system based on the use of the world wide web, increasingly determine the development of educational institutions. With the Internet and web technologies, students and teachers gained the ability to interact in real time regardless of their location. Modern network approach to learning based on virtual technologies could provide for a discussion between student and teacher on the problem. During the discussion, the information comes just in time, helping to formulate tasks and problems that possibly will be considered in the classroom. At the same time there is the possibility of providing feedback that gives the student the opportunity to check the level of understanding of various concepts. The teacher can provide the program participant personal feedback in real time. With the help of networking becomes real to hold virtual seminars on the problems studied by students. [13]

Distance learning helps the student to make a more precise analysis to handle the large volume of the latest information and feedback to consult with teachers in real time. All this accelerates learning and increases its quality. First of all, access to the vast amount of information necessary for learning is provided.
Using feedback, the student is ready to present the results of their work to teachers or fellow students. The interaction may be carried out when the participants find it most useful and convenient. Information technology can significantly facilitate contact via the Internet or servers. The student using electronic means of communication may be in realtime to share the experience. This interactive exchange of knowledge shifts the focus towards interaction, which is becoming one of the most effective ways of teaching where the most pronounced traits of personality-oriented character.

The developers of distance education stress individualized educational behavior in the following way:

1. Flexibility - the student is free to plan the time, place and duration of classes.

2. Modularity - study materials are available in the form of modules that allows the learner to generate the trajectory of their learning in accordance with their requests and potential opportunities.

3. Accessibility - regardless of geographical and temporal position of the student and the educational institution allows not limiting the educational needs of the population.

4. Mobility - effective implementation of the feedback between teacher and student is one of the basic requirements and the reasons for the success of distance education.

5. Coverage - simultaneous treatment of many sources of educational information (electronic libraries, data banks, knowledge bases, etc.) of a large number of students.

6. Adaptability - use in the educational process of the latest achievements of information and telecommunication technologies.

7. Social equity - equal educational opportunities regardless of place of residence, health status, elitism and material security of student.

8. International - export and import of world achievements on the market of educational services. [4]

\section{Conclusion}

In conclusion, we can say that distance learning has huge advantages. But we should not forget about the shortcomings. A truly high-quality education it is impossible to obtain only virtually, remotely. Personal interaction between student and teacher in conjunction with contacts with classmates will always play a significant role. Learning is largely a function of socialization based on the development of perception in the communication of teachers and students. [7]

The lack of personal contact limits the opportunity for learning. The more important problem is creating trusting environment between teacher and student. In the end, trust is the interpersonal category. While learning through a 
virtual network is hardly formed such relationships. Therefore, the richness of the learning process in full only virtual means can not be reproduced. [5]

Distance learning must be additional to class learning associated with the formation of various receptions of educational activity of students. [9]
Obviously, relying on information technology, higher education can raise the level of curricula and teaching. New technologies offer new opportunities to teachers in applying new techniques that enhance the quality of education.

\section{References:}

1. Sigov A.S., Mordvinov V.A. (2001) Mobil'nye informacionnye tekhnologii $\mathrm{V}$ uchebnom processe shkoly i vuza. Magistr, № 5-6, 2001.

2. Gutman S. (2000) Obrazovanie v informacionnom obshchestve $-\mathrm{SPb}$ : EHkstraprint, 2000.

3. Ruliene L.N (2011) Principy distancionnogo obucheniya v kontekste gumanitarnyh cennostej: Materialy n.-p.k. «Teoreticheskie i metodologicheskie problemy sovremennogo obrazovaniya», Moskva - 2011.- 197 p.

4. Fedorova E.F. (1999) Sistemnoe predstavlenie distancionnogo obrazovaniya. Obrazovanie i 21 vek. Informacionnye i kommunikacionnye tekhnologii. M. 1999. p.138.

5. Kutuzov M. N. (2011) Distancionnye tekhnologii obucheniya $\mathrm{v}$ tradicionnom obrazovatel'nom processe [Tekst] // Pedagogika: tradicii i innovacii: materialy Mezhdunar. nauch. konf. (g. CHelyabinsk, oktyabr' 2011 g.).T. II. - CHelyabinsk: Dva komsomol'ca, 2011. - p. 143-146.

6. Meleshko S.V., Popova S.V. (2012) Distancionnye tehnologii kak neobhodimyj komponent vneauditornoj samostojatel'noj raboty studentov pri izuchenii matematiki //Mezhdunarodnyj zhurnal social'nyh nauk. 2012. № 9-1 (25).p. 108 - 115.

7. Zorina E.B. (2012) Innovacionnye tehnologii v prepodavanii inostrannogo jazyka / Modelirovanie proizvodstvennyh processov i razvitie informacionnyh sistem 2012. p. 272274.

8. Gulaj T.A., Meleshko S.V., Nevidomskaja I.A. (2013) Distancionnye tehnologii V informacionno-obrazovatel'noj srede vuza kak neobhodimoe uslovie samostojatel'noj raboty studentov pri izuchenii matematicheskih disciplin // Nauka i obrazovanie v XXI veke: sbornik nauchnyh trudov po materialam Mezhdunarodnoj nauchno-prakticheskoj konferencii: v 34 chastjah. 2013. p. 33-36.

9. Popova S.V., Smirnova N.B., Donec Z.G. (2004) Formirovanie priemov uchebnoj deyatel'nosti studentov $\mathrm{v}$ processe obucheniya matematike // Informacionnye i kommunikacionnye tekhnologii i ih rol' $\mathrm{v}$ aktivizacii uchebnogo processa v vuze: 66-67 nauchno-prakticheskaya konferenciya. 2004. p. 174-180.

10. Zorina E.B. (2010) Klassicheskie i innovacionnye tekhnologii $\mathrm{V}$ prepodavanii inostrannogo yazyka studentam gumanitarnyh special'nostej / Social'no-gumanitarnye znaniya. 2010. № 7. p. 164-167.

11. Demchuk A.A., Kolodyazhnaya T.A. (2005) Primenenie tekhnicheskih sredstv obucheniya v processe matematicheskoj podgotovki studentov inzhenernyh special'nostej / EHkonomika regionov Rossii: analiz sovremennogo sostoyaniya i perspektivy razvitiya: sbornik nauchnyh trudov po materialam Ezhegodnoj 69-j nauchnoprakticheskoj konferencii, posvyashchennoj 75letiyu StGAU. 2005. p. 123-130.

12. Dolgih E.V., Kron R.V. (2012) O distancionnom obrazovanii i opyte ego vnedreniya v sisteme povysheniya kvalifikacii / Innovacionnye vektory sovremennogo obrazovaniya. 2012. p. 43-47.

13. Romanova S.M. (2013) Sistema distancionnogo obucheniya kak sredstvo informacionnokommunikacionnyh tekhnologij V obrazovatel'nom processe // Nauchnometodicheskij ehlektronnyj zhurnal «Koncept». - 2013. - T. 4. - p. 271-275. 


\begin{tabular}{l|lr|ll|ll} 
& ISRA (India) & $\mathbf{1 . 3 4 4}$ & SIS (USA) & $=\mathbf{0 . 9 1 2}$ & ICV (Poland) & $=\mathbf{6 . 6 3 0}$ \\
Impact Factor: & ISI (Dubai, UAE) $=\mathbf{0 . 8 2 9}$ & PUHЦ (Russia) $=\mathbf{0 . 2 0 7}$ & PIF (India) & $=\mathbf{1 . 9 4 0}$ \\
& GIF (Australia) & $=\mathbf{0 . 5 6 4}$ & ESJI (KZ) & $=\mathbf{3 . 8 6 0}$ & IBI (India) & $=\mathbf{4 . 2 6 0}$ \\
& JIF & $\mathbf{1 . 5 0 0}$ & SJIF (Morocco) $=\mathbf{2 . 0 3 1}$ & & \\
\hline
\end{tabular}

